(C) 2016

\author{
Войтенко С. Л., доктор сільськогосподарських наук
}

Полтавська державна аграрна академія

\title{
МОЖЛИВІСТЬ ПІДВЩЕННЯ МОЛОЧНОЇ ПРОДУКТИВНОСТІ У КОРІВ ЛОКАЛЬНИХ ПОРІД
}

\section{Рецензент - доктор сільськогосподарських наук А. А. Полішук}

У статті висвітлені результати досліджень щзодо впливу низки чинників на молочну продуктивність корів білоголової украӥнської породи, яка відноситься до локальної породи молочного напряму продуктивності й утримується лише в одному племінному господарстві. Формування молочної продуктивності корів даної породи узгоджується з походженням тварин та порядковим номером лактаџіï. Найвищим надоєм за 305 днів першої лактації характеризувалися корови ліній Марта 171 і Озона 417, відповідно 4483,1 та 4254,9 к2 молока за варіації ознаки в розрізі ліній у межах 3976,4-4483,1 к2. Встановлено, щуо надій корів заводського стада підвищується до 5-6 лактацій, даючи змогу збільшити тривалість господарського використання більш високопродуктивних корів за збереження генетичної мінливості ознаки. На можливість підвищення надоїв корів методами селекиії вказує коефіцієнт мінливості надоїв корів усіх досліджуваних ліній, окрім Жаргуна 157. Отже, підвищення молочної продуктивності корів української білоголової породи можна здійснювати методами внутрішньопородної селекиії, зберігаючи генофонд цієї локальної вітчизняної популяції великої рогатоі худоби.

Ключові слова: молочна продуктивність, надій корів, лінії, лактаиія, тривалість використання.

Постановка проблеми. Виробництво продукції молочного скотарства на сучасному етапі розвитку галузі тваринництва в Україні та світі узгоджується із поголів'ям корів, їх здатністю продукувати певну кількість молока бажаної якості, вимогами переробної галузі та попитом споживачів. Саме такий підхід до галузі стимулює створення нових порід з бажаними ознаками продуктивності та витіснення з ринку застарілого, менш продуктивного матеріалу $[4,5]$. Проте не дивлячись на породоутворюючий процес, інтенсивне використання мають лише 1-2 породи (голштинська порода великої рогатої худоби, ландрас, йоркшир - свиней, арабська, чистокровна - коней тощо), решта рано чи пізно буде витіснена з ринку виробників продукції назавжди, або на ii генетичному матеріалі будуть створені більш продуктивні популяції.
Галузь молочного скотарства в Україні не $\epsilon$ виключенням, оскільки виробники молока надають перевагу здебільшого трьом сучасним породам: українській чорно-рябій, українській червоно-рябій та українській червоній молочній за щорічного скорочення поголів'я місцевих чи менш продуктивних порід. Для збереження місцевих порід необхідні дві складові: дотації держави для компенсації збитковості утримання тварин, які не будуть конкурентоспроможними в ринкових відносинах, або розробка методів підвищення продуктивності до рівня, що забезпечить їх інтенсивне використання в галузі. Перший чинник проблематичний, тому необхідно розглянути можливість підвищення продуктивності тварин локальних порід за збереження генетичної мінливості популяції.

У якості об'єкта досліджень вибрано білоголову українську породу великої рогатої худоби, яка була створена та використовувалася в переважній більшості в поліській кліматичній зоні, але 3 огляду на невисоку молочну продуктивність витісняється з ринку виробників молока [1]. Саме тому розробка методів селекції, які б забезпечили підвищення надоїв корів за чистопородного розведення, $є$ актуальною проблемою сьогодення.

Аналіз останніх досліджень і публікацій, у яких започатковано розв'язання проблеми. Загальновідомо, що продуктивність сільськогосподарських тварин зумовлена низкою фізіологічних процесів організму і $є$ результатом взаємодії генів, які формують спадковість породи й забезпечують тваринам прояв тих чи інших ознак продуктивності.

Молочна продуктивність корів, як і будь-яка інша, зумовлюється взаємодією «генотипсередовище» $[6,12,8]$, в числі яких належність тварин до породи чи лінії, походження за батьком та матір'ю, умовна кровність за поліпшувальною породою, вік та сезон отелення, тривалість використання, годівля тварин, умови їх вирощування, технологія тощо [3, 7, 9-11].

Під час розведення місцевих порід сільськогосподарських тварин низка чинників не узгоджу- 


\section{СІЛЬСЬКЕ ГОСПОДАРСТВО. ТВАРИННИЦТВО}

ються між собою, а саме: необхідність збереження комплексу генів, характерних для даної популяції та бажання підвищувати продуктивність тварин до рівня, який забезпечує рентабельність виробленої від них продукції. Відмова від першої приведе до знищення генофонду породи та їі цілісності з генетичної точки зору, хоча й сприятиме підвищенню рівня продуктивності тварин. Відмова від другої взагалі знищить породу, як складову галузі. Саме тому необхідно знайти ті фактори, які б дали змогу зберегти генофонд популяції та підвищити рівень молочної продуктивності корів до стану рентабельності виробництва продукції від них.

Мета і завдання досліджень - аналіз молочної продуктивності корів української білоголової породи та розробка методів їі підвищення за чистопородного розведення тварин.

Матеріали і методи досліджень. Аналіз стану білоголової української породи зроблено за результатами обстеження племінного заводу ТОВ «Подільський господар» Хмельницької області у 2015 році.

Визначення молочної продуктивності корів у розрізі лактацій (I-VII лактації) та ліній (Рєзвого 33, Жаргуна 157, Озона 417 і Марта 171) проведено за матеріалами електронної інформаційної бази даних господарства. Надій корів ураховували за 305 днів лактації. Статистичне опрацювання матеріалів власних досліджень зроблено за використання програмного пакету «STATISTICA 6.0» на ПК.

Результати досліджень. Встановлено, що виробництво молока від корів білоголової української породи в умовах ТОВ «Подільський господар» Хмельницької області здійснюється за потоково-цехової технології та прив'язного утримання корів у цеху виробництва молока. Вік першого осіменіння телиць 18-19 місяців, вихід телят на 100 корів - 65-70 \%. Корови даної породи зараз - це тварини вираженого молочного типу, ніжної міцної конституції, 3 глибокими грудьми, прямою й широкою спиною, тонкими ногами, великим вим'ям 3 рівномірно розвине- ними частками. У переважній більшості корови стада мають чорне забарвлення, білу голову 3 «окулярами» навколо очей, здебільшого білі черево та вим'я, а також нижні частини ніг і китицю хвоста.

Оцінювання корів за молочною продуктивністю дало змогу виявити деякі особливості даної популяції, які можуть бути враховані під час створення консолідованої, конкурентоспроможної породи.

Нашими дослідженнями встановлено, що найвищим надоєм за 305 днів першої лактації характеризувалися корови, які належали до ліній Марта 171 і Озона 417, відповідно 4483,1 та 4254,9 кг молока за варіювання ознаки у залежності до ліній в межах 3976,4-4483,1 кг (табл. 1). Дещо нижча продуктивність корів ліній Рєзвого 33 та Жаргуна 157 за першим отеленням може зумовлюватися не поєднуваністю спадкової основи батьківських форм та племінною цінністю бугаяплідника, який загалом суттєво впливає на продуктивність дочок.

Проте навіть серед менш продуктивних ліній у стаді є тварини 3 досить високими надоями, про що свідчить похибка досліджуваної ознаки $(\mathrm{m}=117,84 \ldots 263,85)$.

Тому як варіант створення однорідних ліній в стаді та породі може бути менший відсоток вибракуваних корів зі стада, або введення лише тих первісток, які перевищують середню продуктивність корів у стаді. Крім того, як елемент селекційної роботи зі стадом тварин даної локальної популяції необхідний правильний вибір бугаяплідника для відтворення стада.

До корів, які мають високу продуктивність, краще добирати плідників тих ліній, до яких належать і корови, уникаючи спорідненого розведення.

До корів, що характеризуються не високою продуктивністю, краще добирати плідників інших ліній, застосовуючи крос лінії, що в кінцевому результаті повинно привести до одержання потомства з кращою якістю, ніж у матері.

\section{1. Молочна продуктивність корів-первісток білоголової украӥнської породи в залежності від лінії}

\begin{tabular}{|c|c|c|c|c|c|}
\hline \multirow{2}{*}{ Лінія } & \multirow{2}{*}{$\mathrm{n}$} & Надій, кг (305 днів лактації) & \multicolumn{2}{|c|}{ Молочний жир } \\
\cline { 3 - 6 } & & $M \pm m$ & $C v, \%$ & $\%$ & \multirow{2}{*}{$\%$} \\
\hline Рєзвого 33 & 24 & $4048,9 \pm 263,85$ & 31,9 & $3,6 \pm 0,02$ & $146,3 \pm 9,29$ \\
\hline Жаргуна 157 & 5 & $3976,4 \pm 117,84$ & 6,6 & $3,6 \pm 0,03$ & $141,8 \pm 5,05$ \\
\hline Озона 417 & 257 & $4254,9 \pm 55,33$ & 20,6 & $3,6 \pm 0,01$ & $154,2 \pm 2,09$ \\
\hline Марта 171 & 7 & $4483,1 \pm 221,53$ & 13,0 & $3,7 \pm 0,03$ & $163,4 \pm 8,72$ \\
\hline
\end{tabular}


2. Молочна продуктивність корів білоголової украӥнської породи у залежнності від лактації

\begin{tabular}{|c|c|c|c|c|}
\hline \multirow{2}{*}{ Лактація } & \multirow{2}{*}{$\mathrm{n}$} & \multirow{2}{*}{$\begin{array}{c}\text { Надій, кг } \\
\text { (305 днів лактації) }\end{array}$} & $\%$ & Молочний жир \\
\cline { 4 - 5 } & 115 & $4190,9 \pm 87,77$ & $3,6 \pm 0,01$ & $152,2 \pm 3,27$ \\
\hline I & 55 & $4106 \pm 101,83$ & $3,6 \pm 0,01$ & $148,0 \pm 3,98$ \\
\hline II & 24 & $4362,2 \pm 285,77$ & $3,6 \pm 0,01$ & $156,7 \pm 10,16$ \\
\hline III & 12 & $4934,7 \pm 342,31$ & $3,6 \pm 0,02$ & $179,3 \pm 12,70$ \\
\hline IV & 5 & $5473,4 \pm 164,78$ & $3,7 \pm 0,02$ & $200,0 \pm 5,97$ \\
\hline V & 3 & $5539,7 \pm 652,75$ & $3,6 \pm 0,04$ & $204,3 \pm 25,98$ \\
\hline VI & 4 & $4034,3 \pm 496,19$ & $3,6 \pm 0,03$ & $144,5 \pm 18,07$ \\
\hline VII & & & & \\
\hline
\end{tabular}

Ротація ліній у стаді з невеликою чисельністю корів повинна бути не значною. Краще повторювати вдалі поєднання, зменшуючи генетичну мінливість ознаки в стаді.

На можливість покращання надоїв корівпервісток у стаді методами селекції, крім лінії Жаргуна 157, вказує коефіцієнт мінливості ознаки, який знаходився в межах 13,0-31,9\%. Коровипервістки досліджуваних ліній суттєво не відрізнялися між собою за вмістом жиру в молоці (3,6-3,7\%), вказуючи на досить високу якість продукції. В наших дослідженнях вміст жиру в молоці не корелює із надоями корів-первісток, тому селекція на підвищення надоїв у первісток не узгоджуватиметься із підвищенням молочного жиру. Кількість молочного жиру у корів за першу лактацію залежала від їх надоїв та вмісту жиру в молоці і найбільшою була у представниць ліній Марта 171 та Озона 417, відповідно 163,4 та 154,2 кг.

На встановлення позитивного зв'язку надоїв корів із порядковим номером лактації вказано в роботах багатьох дослідників, які вважають, що надій корів підвищується до 5-6 лактації, а потім відбувається його зменшення. Цей фактор інтенсивно використовують у молочному скотарстві, особливо за селекції на довголіття корів. Ураховуючи, що поголів'я корів української білоголової породи нараховує лише 300 голів, а вихід телят на 100 корів 65-70\%, бажано визначити оптимальний вік корови, або кількість лактацій, протягом яких тварина збільшуватиме молочну продуктивність.

Дослідження в цьому напрямі засвідчили можливість використання корів у стаді досить довго протягом 5-6 лактацій (табл. 2).

Так, використання корів протягом трьох лак-

\section{БІБЛІОГРАФІЯ}

1. Бірюкова K. C. Білоголова українська порода / К. С. Бірюкова // Племінна робота з породами тацій підвищить їх продуктивність на 171,3 кг порівняно із первістками, чотирьох лактацій - на 744,7 кг, п'ятьох лактацій - на 1282,5 кг, шістьох - на 1348,8 кг. Виключенням для стада є корови 3 двома лактаціями, які продукують менше молока, ніж первістки та значно менше, ніж корови із вищою кількістю лактацій. Слід також наголосити на тому, що до п'ятої-шостої лактації в стаді доживає досить мало корів, але виявлена тенденція переконує не вибраковувати корів після другої лактації, а залишати їх для відтворення ще декілька років. Нами не встановлено суттєвого впливу порядкового номеру лактації на збільшення вмісту жиру в молоці за протилежної тенденції із кількістю молочного жиру, який збільшувався у відповідності до підвищення надоїв корів за лактаціями.

Отже, проведені дослідження довели, що молочна продуктивність корів української білоголової породи зумовлюється походженням та тривалістю господарського використання (кількістю лактацій), а відтак є всі умови для збереження та якісного вдосконалення даної локальної породи методами внутрішньопородної селекції.

Висновок. Для того, щоб українська білоголова порода великої рогатої худоби була конкурентоспроможною, необхідно консолідувати корів за молочною продуктивністю шляхом добору тих, які відповідають стандарту породи чи перевищують його на 10-20 \%. Якомога довше використовувати високопродуктивних корів у стаді 3 урахуванням висновку про збільшення їх надоїв до п'ятої-шостої лактації. Відмовитися від кросування ліній, зосередивши увагу на лінійному розведенні тварин за визначеної поєднуваності батьківських форм.

великої рогатої худоби. - К., 1963. - С. 272-293.

2. Вплив генетичних та паратипових чинників 
на господарські корисні ознаки корів / [Гладій М. В., Полупан Ю. П., Базишина I. В., Безрутченко I. М. та ін.] // Розведення та генетика тварин. - 2014. Вип. 48. - С. 48-61.

3. Генотипові та паратипові чинники впливу на ознаки молочної продуктивності корів молочних порід сумського регіону / [Хмельничий Л. М., Салогуб А. М., Жмурко С. М., Корнієнко Т. І., Котов Б. В., Сіряченко О. О., Соколов А. Ю.] // Вісник Сумського НАУ. Серія «Тваринництво». 2011. - Вип. 7 (19). - С. 25-29.

4. Зубецьь M. В. Система племінної роботи як засіб виробництва при формуванні порід, що відповідають вимогам ринку / М. В. Зубець, С. Ю. Рубан // Розведення і генетика тварин. 2010. - Вип. 44. - С. 3-10.

5. Стан і перспективи порідного удосконалення молочного скотарства і відновлення системи селекції бугаїв / Бащенко М. І., Полупан Ю. П., Рубан С. Ю., Базишина І. В. // Розведення і генетика тварин. - 2012. - Вип. 46. - С. 79-83.

6. Охапкин C. К. Генотип, среда и потенциал продуктивности молочного стада / С. К. Охапкин, Ю. И. Рожков // Зоотехния. - 1993. - №7. C. 2-5.

7. Полупан Ю. П. Ефективність довічного використання корів різних країн селекції / Ю. П. По- лупан // Вісник СНАУ. Серія «Тваринництво». Суми, 2014. - Вип. 2/2 (25). - С. 14-20.

8. Реакція великої рогатої худоби на деякі фактори середовища / [Савчук Д. І., Полупан Ю. П., Сахацький П. С., Гаєвий В. В.] // Біологія тварин. 2001. - T. 3. - №1. - С. 70-72.

9. Ставецька Р. В. Ефективність відбору корів української чорно-рябої молочної породи за походженням / Р. В. Ставецька // Вісник Сумського НАУ. Серія «Тваринництво». - Суми, 2013. Вип. 1 (22). - С. 78-82.

10. Федорович $C$. Вплив батьків на формування молочної продуктивності дочок / Є. Федорович, Й. Сірацький // Тваринництво України. 2005. - №2. - C. 15-17.

11. Ящук T. С. Вплив генотипних чинників на тривалість експлуатації корів української чорнорябої молочної породи / Т. С. Ящук // Розведення і генетика тварин. - К. : Аграрна наука, 2011. Вип. 45. - С. 331-340.

12. Identification of factors that cause genotype by environmental interaction between herds of holstein cattle in seventeen countries / [Zwald N. R., Weigel K. A., Fikse W. F., Rekaya R.] // Journal of Dairy Science. - 2003. - V. 86. - P. 1009-1018. 